\title{
Atria score to predict atrial fibrillation in acute ischemic stroke patients
}

\section{Akut iskemik inmeli hastalarda atriyal fibrilasyonu öngörmek için atria skoru}

\author{
Gunes Hakan
}

Kahramanmaras Sütcü İmam University, Faculty of Medicine, Department of Cardiology/ Kahramanmaras, Turkey

Corresponding author: Assist Prof. Gunes Hakan, MD., Kahramanmaraş Sütçü İmam University, Faculty of Medicine, Department of Cardiology Kahramanmaraș, Turkey

E-mail: drhakangunes83@hotmail.com

Received/Accepted: February 01, 2019 / February 25, 2019

Conflict of interest: There is not a conflict of interest.

\section{SUMMARY}

Objective: Atrial fibrillation is closely associated with ischemic stroke. Ischemic stroke has been shown to be more frequent in patients with atrial fibrillation than the normal population. The predictive factors of atrial fibrillation in patients with ischemic stroke have been investigated in several studies. The aim of this study is to reveal the relationship with atrial fibrillation and ATRIA score in ischemic stroke patients.

Method: 104 patients who suffered a cerebrovascular event in sinus rhythm were included in the study. Patients were divided into two groups as detected or undetected diagnosed atrial fibrillation in 24-hour Holter ECG monitoring applied during hospitalization. The ATRIA risk score was calculated for all patients.

Results: Average of ATRIA score was found to be significantly higher in the group with detected atrial fibrillation $(\mathrm{P}=$ 0.001). The optimal cut-off value for ATRIA score to predict atrial fibrillation was $>5$ with a specificity of $78.4 \%$ and a sensitivity of $83.3 \%$ (area under the curve 0.866 ; 95\% confidence interval (CI), 0.786-0.924, p<0.001). The ATRIA score and its components had important significance in the univariate analysis. ATRIA score and ejection fraction $(\mathrm{OR}=1.360,95 \%$ CI: 1.090-1.697, $\mathrm{p}=0.006$; OR $=0.900,95 \%$ CI: 0.834-0.971, $\mathrm{p}=0.007$ respectively) were observed to be associated with atrial fibrillation in the multivariate regression analysis.

Conclusions: There is an independent relationship between the ATRIA score and the development of atrial fibrillation, in patients with ischemic stroke in sinus rhythm.

Keywords: ATRIA score, atrial fibrillation, ischemic stroke

\section{ÖZET}

Amaç: Atrial fibrilasyon ile iskemik inme yakından ilişkili olup iskemik inme geçiren hastalarda atriyal fibrilasyon ataklarının normal popülasyona oranla daha fazla olduğu gösterilmiştir. İskemik inme geçiren hastalarda atriyal fibrilasyonu ön gördürücü etkenler birçok çalışmada araştırılmıştır. Bu çalışmanın amacı da iskemik inme hastalarındaki ATRİA skorlama sisteminin atriyal fibrilasyonla ilişkisini ortaya koyabilmektir.

Yöntem: Çalışmaya sinüs ritminde serebrovasküler olay geçiren 104 hasta dahil edildi. Hastalar hastanede yatış esnasında uygulanan 24 saatlik holter EKG takiplerinde atriyal fibrilasyon atağı olanlar ve olmayanlar olarak iki gruba ayrıldı. Tüm hastaların ATRİA skorları hesaplandı.

Bulgular: ATRİA skor ortalamas1 atriyal fibrilasyon tespit edilen grupta anlamlı oranda yüksek bulundu. $(\mathrm{p}=0.001)$ ATRİA skorunun atriyal fibrilasyonu predikte ettiği cut-off değeri $\% 83.3$ sensitivite ve $\% 78.4$ spesifite ile 5 bulundu (AUC=0,866; \%95 CI, 0.786-0.924, p<0.001). ATRİA skoru ve komponentleri tek değişkenli analizde önemli prognostik öneme sahipti. Çok değişkenli regresyon analizinde, ATRİA skoru ve ejeksiyon fraksiyonun $(\mathrm{OR}=1.360$, 95\% CI: 1.090-1.697, $\mathrm{p}=0.006$;OR $=0.900,95 \%$ CI: 0.834-0.971, $\mathrm{p}=0.007$ sırası ile ) atriyal fibrilasyon atağ ile ilişkili olduğu görüldü.

Sonuç: Sinüs ritminde serebrovasküler olay geçiren hastalarda atriyal fibrilasyon gelişmesi ile ATRİA skoru arasında bağımsız bir ilişki vardır.

Anahtar sözcükler: ATRİA skoru, atriyal fibrilasyon, iskemik serebrovasküler olay 


\section{INTRODUCTION}

Ischemic strokes are responsible for $20 \%$ of cardioemboli ${ }^{1}$. Atrial fibrillation has an important place in the etiology of cardioemboli and atrial fibrillation is seen in half of cardio embolic patients. Additionally, atrial fibrillation is responsible not only for cardio embolic strokes but also one-sixth of all strokes. Moreover, the presence of atrial fibrillation increases the risk of stroke five times ${ }^{2}$. Because of the fact that atrial fibrillation and ischemic stroke are so closely associated, there has been a focus on the relationship between atrial fibrillation and stroke. Atrial fibrillation was shown to be more frequent in ischemic stroke patients than the normal population $^{3}$. Identifying atrial fibrillation attacks in patients who have a high risk for atrial fibrillation can prevent possible morbidity and mortality due to stroke.

$\mathrm{CHA}_{2} \mathrm{DS}_{2}$-VASc score is used for both the risk and treatment planning in stroke patients. It has been shown that newly developed ATRIA score has do better risk assessment than $\mathrm{CHA}_{2} \mathrm{DS}_{2^{-}}$ VASc in the recently held two large communitybased registry studies ${ }^{4-5}$. Each component which constitutes these risk scoring systems is an independent risk factor for atrial fibrillation. The predictive factors of atrial fibrillation in patients with ischemic stroke have been investigated in several studies ${ }^{6-9}$. In this study, we investigated the relationship between the ATRIA score and

Table-1 ATRIA and CHA2DS2-VASc SCORE atrial fibrillation in patients with ischemic stroke in sinus rhythm .

\section{MATERIAL AND METHODS}

\section{Study Population:}

For this prospective study 104 patients who hospitalized with a diagnosis of ischemic stroke were included. Inclusion criteria were determined as being older than 18 years of age and written consent to participate in the study was taken. The patients who had atrial fibrillation in ECG, mechanical prosthetic valves, previously known paroxysmal atrial fibrillation, severe valve stenosis and regurgitation, patients who cannot be followed by Holter ECG and patients who found out to have atrial septal defect and patent foramen ovale in echocardiography control were not included in the study.

All patients underwent echocardiographic examination and 24-hour Holter ECG follow-up by a cardiologist.

Basic demographic and clinical data (age, sex, hypertension, diabetes mellitus, coronary heart disease, heart failure, stroke or ischemic attack and tobacco use) of the study population were recorded. ATRIA and CHA2DS2-VASc scores of all patients were calculated. Urinary proteinuria was measured for atria scoring and glomerular filtration rate was calculated at admission. Components of ATRIA and $\mathrm{CHA}_{2} \mathrm{DS}_{2}$-VASc scoring systems are shown in Table 1.

\begin{tabular}{|c|c|c|}
\hline \multicolumn{3}{|l|}{ Stroke Risk Stratification With The ATRIA Score } \\
\hline Risk Factor & Score Without Prior Stroke & Score With Prior Stroke \\
\hline Age $\geq 85$ & 6 & 9 \\
\hline Age $75-84$ & 5 & 7 \\
\hline Age $65-74$ & 3 & 7 \\
\hline Age $<65$ & 0 & 8 \\
\hline Female sex & 1 & 1 \\
\hline Diabetes mellitus; & 1 & 1 \\
\hline Congestive heart failure & 1 & 1 \\
\hline Hypertension & 1 & 1 \\
\hline Proteinuria & 1 & 1 \\
\hline $\mathrm{eGFR}<45 \mathrm{~mL} / \mathrm{min} / 1.73 \mathrm{~m} 2$ or ESRD & 1 & 1 \\
\hline \multicolumn{3}{|l|}{ Stroke Risk Stratification With The CHA2DS2-VASc } \\
\hline Risk factor & Score & \\
\hline $\mathrm{C}$ - Congestive heart failure; & 1 & \\
\hline H-Hypertension & 1 & \\
\hline A- Age $\geq 75$ & 2 & \\
\hline D- Diabetes mellitus & 1 & \\
\hline S-Stroke & 2 & \\
\hline V- Vascular disease (prior MI, PAD, or aorticplaque) & 1 & \\
\hline A- Age $65-74$ & 1 & \\
\hline S- Sex Female & 1 & \\
\hline
\end{tabular}


Abbreviations: ATRIA, Anticoagulation and Risk Factors in Atrial Fibrillation; eGFR, estimated glomerular filtration rate; ESRD, end-stage renal disease

In order to perform the $24 \mathrm{~h}$ Holter monitoring, the 3-Channel recordings with standard settings (Walk 400h Cardioline, Milan, Italy) were used. The recordings gained from patients for the presence of $<30$ s-long or $\geq 30$-s-long $\mathrm{AF}$ episodes were evaluated by an experienced cardiologist who had no information about the characteristics of patients. Supraventricular runs with $>3$ beats, lasting $<30 \mathrm{~s}$ with absolutely irregular $\mathrm{RR}$ interval and no distinct $\mathrm{p}$-waves were contemplated as non-sustained AF. Selfterminating episodes which had similar morphological characteristics and lasting $\geq 30$ $\mathrm{s}$ were regarded as paroxysmal AF.

\section{Standard Echocardiography}

Transthoracic echocardiographic examinations was undertaken by experienced echocardiographers who had no information about the clinical details of each subject using the Vivid $7^{\circledR}$ cardiac ultrasonography system (GE VingMed Ultrasound AS; Horten, Norway) with 2.5- to 5-MHz probes. For each patient, the left lateral and supine positions by 2D, M-mode, pulsed, and color flow Doppler echocardiography examination was carried on. Single lead electrocardiogram was unceasingly recorded. The average of at least three cardiac cycles was obtained for all measurements. The basis of examination of M-mode measurements and conventional doppler echocardiographic examinations was performed according to European Society of Echocardiography guideline criteria ${ }^{10}$. Doppler tracings and two-dimensional images were obtained from parasternal long and short axes, apical and subcostal views. Measurement of left and right atrial dimension, end-systolic and end-diastolic dimensions of left ventricle (LV), diastolic LV posterior, and septal wall thicknesses was carried on. Estimation of LV ejection fraction (EF) was done through Simpson's rule and measurement of left atrial volumes was conducted through disc method.

\section{Statistical Analysis}

For data management and analysis the SPSS program version 14 (SPSS Inc., Chicago, IL, USA) was used and a two-sided $p$-value $\leq$ 0.05 was found out to be statistically significant. Categorical variables were shown as the number of cases plus percentage and continuous variables as mean \pm standard deviation (SD) or median and interquartile ranges (IQR), where usable. An independent sample $t$ test was used for comparison of means and a Mann-Whitney U test was used with median if there was no normal distribution. The chi square test was used for appropriate categorical data evaluation. Pearson correlation test was used for normally distributed variables and for non-normally distributed variables for correlation analysis performance, Spearmen correlation test was used. Identification of the optimal cut-off point of ATRIA score for the prediction of $\mathrm{AF}$ was done through receiver operator characteristic (ROC) curve analysis. ROC curve analysis was done using MedCalc (v12.7.8). The area under the curve (AUC) with $95 \%$ confidence interval was estimated in prediction of AF. The optimal cutoff value of ATRIA score was identified as the value parallel with the highest sum of sensitivity and specificity-1. Univariate analysis was used for quantification of the relationship of variables with $\mathrm{AF}$. The variables found out to be statistically significant in the univariate analysis and other potential confounders were used in multivariate logistic regression model with backward stepwise method for identifying independent prognostic factors of AF.

\section{RESULTS}

Upon the analysis of Holter ECG recordings of 104 patients included in the study, 18 patients were detected to have AF attacks, while 88 patients had sinus rhythm. Among patients with AF attacks, 3 of them had PAF and 15 of them had non-sustained AF. 
Clinical, laboratory and echocardiographic data of two groups were formed according to the presence of AF were shown in Table 2. Coronary artery disease, proteinuria, previous stroke, age, $\mathrm{CHA}_{2} \mathrm{DS}_{2}$-VASc and ATRIA score were significantly higher in the group developing AF attacks, but there were no significant differences between groups regarding sex and other laboratory findings. Among standard echocardiographic measurements, left atrial dimensions were significantly increased and EF decreased in the group with AF attacks.

Table 2 :Baseline characteristics of study patients.

\begin{tabular}{|l|l|l|l|}
\hline & Without AF Attacks (n= 88) & AF Attacks (n=18) & $\mathrm{p}$ \\
\hline Age,years & $63 \pm 11$ & $72 \pm 12$ & 0.04 \\
\hline CHA2DS2-VASc score & $2(1-3)$ & $4(2.75-5)$ & $<0.001$ \\
\hline ATRIA score & $3(1-5)$ & $6(4-7.5)$ & $<0.001$ \\
\hline Hypertension, n (\%) & $40(45 \%)$ & $8(44 \%)$ & 0.938 \\
\hline Diabetes mellitus, $\mathrm{n}(\%)$ & $33(38 \%)$ & $9(50 \%)$ & 0.325 \\
\hline Female/ Male,(n \%) & $37 / 51$ & $10 / 8$ & 0.429 \\
\hline Proteinuria (n\%) & $4(5 \%)$ & $4(22 \%)$ & 0.027 \\
\hline Previous stroke (n\%) & 0 & $4(22 \%)$ & $<0.001$ \\
\hline $\begin{array}{l}\text { Coronary Artery Disease/ } \\
\text { Peripheral Artery }\end{array}$ & $22(25 \%)$ & $10(55 \%)$ & 0.010 \\
Disease(n) & & & \\
\hline Blood glucose,mg/dL & $108(98-148)$ & $143(95-157)$ & 0.310 \\
\hline BUN, mg/dL & $24(15-35)$ & $17.5(13.75-28.25)$ & 0.126 \\
\hline Creatinine, mg/dL & $0.85(0.61-1.1)$ & $0.89(0.71-1.0)$ & 0.610 \\
\hline Uric acid, mg/dL & $5.0 \pm 1.6$ & $5.2 \pm 1.5$ & 0.747 \\
\hline Sodium, mg/dL & $139.8 \pm 3.2$ & $140 \pm 2$ & 0.315 \\
\hline Potassium, mg/dL & $4.8 \pm 0.43$ & $4.7 \pm 0.13$ & 0.560 \\
\hline Hemoglobin, g/dL & $13.9 \pm 2.2$ & $13.2 \pm 2.07$ & 0.266 \\
\hline Echocardiographic Parameters & & \\
\hline EF, \% & $58(55-65)$ & $55(43-85)$ & $<0.001$ \\
\hline LVDD, mm & $4.2 \pm 0.46$ & $4.02 \pm 0.45$ & 0.33 \\
\hline LVSD, mm & $3.3 \pm 0.57$ & $3.1 \pm 0.63$ & 0.21 \\
\hline LA diameter, cm & $3.5 \pm 0.3$ & $3.8 \pm 0.3$ & $<0.01$ \\
\hline
\end{tabular}

EF: Ejection fraction, LVDD: Left ventricule end diastolic dimension, LVSD: Left ventricule end systolic dimension , LA: Left atrium, Data are presented as mean \pm standard deviation (SD) number and percentage, or median and interquantile range (IQR). $\mathrm{p} \leq 0.05$ was considered statistically significant.

It was found out that ATRIA score was positively correlated with hypertension, diabetes mellitus, age, left atrial diameter,
$\mathrm{CHA}_{2} \mathrm{DS}_{2}$-VASc score and coronary artery disease while it was negatively correlated with ejection fraction (Table 3). 
Table 3. Correlation co-efficients for ATRIA SCORE

\begin{tabular}{|l|l|l|}
\hline \multicolumn{3}{|l|}{ Variables Correlating with ATRIA SCORE } \\
\hline & $\mathrm{R}$ & $\mathrm{P}$ \\
\hline Age & 0.827 & $<0.001$ \\
\hline Diabetes mellitus & 0.278 & 0.009 \\
\hline Hypertension & 0.301 & 0.004 \\
\hline CHA2DS2-VASc & 0.864 & $<0.001$ \\
\hline Ejection fraction & -0.524 & $<0.001$ \\
\hline LA diameter & 0.505 & $<0.001$ \\
\hline $\begin{array}{l}\text { Coronary Artery } \\
\text { Disease }\end{array}$ & 0.215 & 0.044 \\
\hline
\end{tabular}

Optimal cut-off time of ATRIA score to predict $\mathrm{AF}$ was found to be $>5 \mathrm{~ms}$, with specificity of
$83.3 \%$ and sensitivity of $78.4 \%$ (AUC $=0.866$; 95\% CI, 0.786-0.924; $p<0.0001$ (Figure 1).

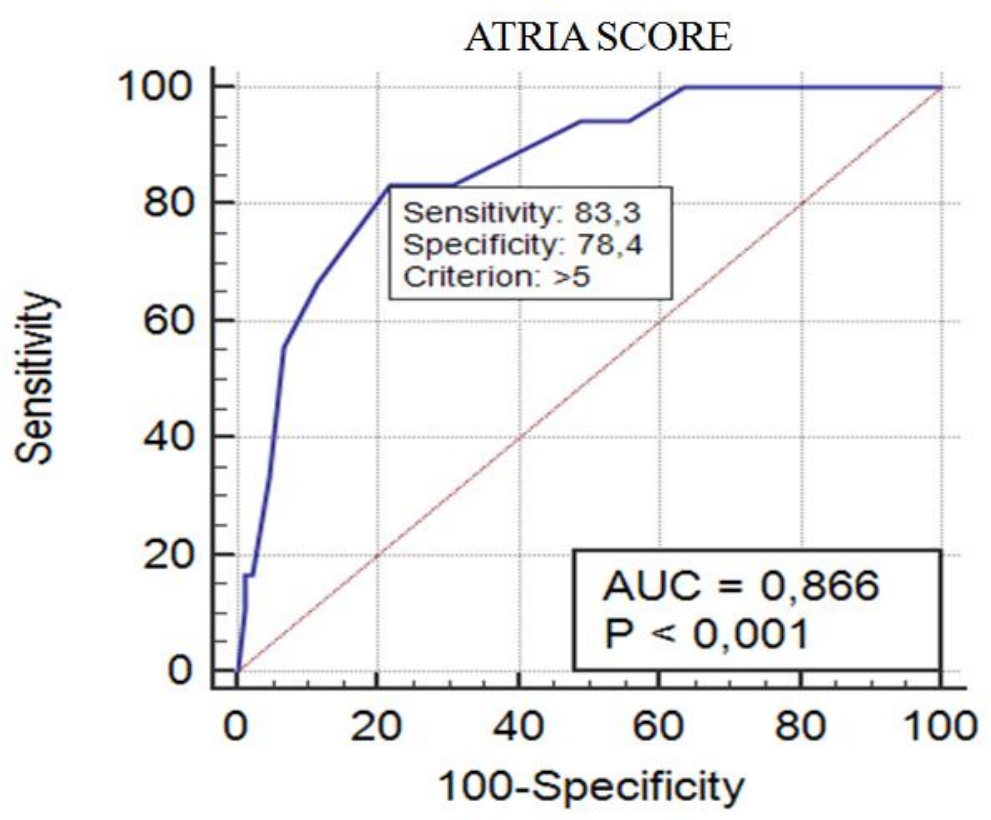

Figure-1: Receiver operator characteristic (ROC) Curve of ATRIA score to predict AF.

In the multiple logistic regression model using a back ward stepwise method, ATRIA score (OR = 1.360, 95\% CI: $1.090-1.697, p=0.006)$ and $\mathrm{EF}$ $(\mathrm{OR}=0.900,95 \%$ CI: $0.834-0.971 p=0.007)$ still remained significant predictors of $\mathrm{AF}$ after adjusting for the confounding variables, which were either found to be statistically significant in the univariate analysis and for the variables correlated with the ATRIA score (Table 4). 
Table 4. Univariate and multivariate analysis for predicting atrial fibrillation

\begin{tabular}{|c|c|c|c|c|c|c|}
\hline & \multicolumn{3}{|c|}{ Univariate Analysis } & \multicolumn{3}{|c|}{ Multivariate Analysis } \\
\hline & $\mathrm{P}$ & OR & $\% 95 \mathrm{CI}$ & $\mathrm{P}$ & OR & $\% 95 \mathrm{CI}$ \\
\hline ATRIA SCORE & $<0.001$ & 1.429 & $1.172-1.743$ & 0.006 & 1.360 & $1.090-1.697$ \\
\hline Ejection fraction & 0.001 & 0.885 & $0.825-0.950$ & 0.007 & 0.900 & $0.834-0.971$ \\
\hline CHA2DS2-VASc & $<0.001$ & 2.003 & $1.364-2.941$ & & & \\
\hline Previous Stroke & 0.019 & 2.058 & $1.041-3.005$ & & & \\
\hline Age & 0.003 & 1.077 & $1.020-1.136$ & & & \\
\hline $\begin{array}{l}\text { Coronary Artery Disease/ Peripheral } \\
\text { Artery Disease }\end{array}$ & 0.001 & 17.000 & 4.469-64.671 & & & \\
\hline Proteinuria & 0.019 & 6.000 & $1.343-26.808$ & & & \\
\hline LA diameter & 0.001 & 11.403 & $2.690-48.336$ & & & \\
\hline \multicolumn{7}{|c|}{ Variables which correlated with epicardial adipose tissue } \\
\hline Hypertension & 0.006 & 6.282 & $1.697-23.259$ & & & \\
\hline Diabetes mellitus & 0.006 & 4.781 & $1.559-14.657$ & & & \\
\hline
\end{tabular}

All the variables from Table 1 were examined and only those significant at a $p<0.05$ level and those with a correlated ATRIA SCORE level are shown in univariate analysis.

The multivariate logistic regression model included all univariate predictors and those with correlated ATRIA SCORE level.

CI: Confidence interval; OR: Odds ratio, Abbreviations in Table 2.

\section{DISCUSSION}

In this study, we found out that ATRIA score was independently related to AF attacks detected by 24-h Holter ECG recordings patients who with acute stroke in sinus rhythm. $\mathrm{CHA}_{2} \mathrm{DS}_{2}-\mathrm{VASc}$ score is used to evaluate the cardioemboli risk in patients with $\mathrm{AF}$ and to plan treatment while ATRIA score is used for risk assessment of cardioemboli. The parameters such as age, sex, diabetes mellitus, congestive heart failure, arterial hypertension, coronary artery disease located in each scoring systems are also independent predictors for atrial fibrillation development ${ }^{11-13}$. It is an expected finding that these scoring systems had predicted atrial fibrillation. Indeed, it is shown that $\mathrm{CHA}_{2} \mathrm{DS}_{2}$-VASc and CHADS scores predicted atrial fibrillation in patients who had ischemic stroke or not ${ }^{9,14-15}$. A study conducted by Liu et al. with 1315 patients revealed that $\mathrm{CHA}_{2} \mathrm{DS}_{2}$-VASc score was an independent predictor of atrial fibrillation. In our study, it was found out that there was no predictor for atrial fibrillation in multivariate analysis although it was found out to be significant in univariate analysis. This can be explained that the small number of patients were included in the study. Another reason may be that diabetes mellitus, congestive heart failure, and arterial hypertension which are the components of $\mathrm{CHA}_{2} \mathrm{DS}_{2}$-VASc score were similar in both groups. In our study, ATRIA score was used as well as the $\mathrm{CHA}_{2} \mathrm{DS}_{2}$-VASc score. It was found out that if ATRIA score was 5 or higher in ischemic stroke patients, it was an independent predictor for atrial fibrillation attacks. There were made a more detailed classification for age in ATRIA score unlike $\mathrm{CHA}_{2} \mathrm{DS}_{2}$-VASc and CHADS scores and the points given to age was higher than the other components. Revised cerebrovascular events were evaluated in combination with age in contrast with other scoring systems. Making the age criteria which is the leading risk factor forefront can explain the fact that ATRIA score is an independent predictor for atrial fibrillation in our study. Additionally, giving the second highest score for age to the patients who had stroke younger than 65 years age may have helped to predict paroxysmal atrial fibrillation. In our study, three patients were observed to have paroxysmal atrial fibrillation attacks and those patients were under 65 years age. In our study, there was no relation between hypertension, diabetes mellitus, heart failure and history of stroke and atrial fibrillation in multivariate analysis although there was a strong relation in univariate analysis. This can be explained by the fact that the number of patients included in the study was low and the prevalence of these diseases was high in the study group. On the other hand, it was found that low EF was associated with atrial fibrillation in both univariate and multivariate analysis. Another important risk factor for atrial fibrillation is heart failure. Intracardiac pressure increase causes atrial wall tension and remodeling in atrial wall in heart failure and predisposes to atrial fibrillation ${ }^{16}$. Consistent with the literature, our study also revealed that EF decrease was found as an independent predictor for atrial fibrillation in patients who has cerebrovascular events. 


\section{CONCLUSION}

As the result, following the rhythm of the patients who had cerebrovascular events in sinus rhythm with high Atria score will not only help the diagnosis of atrial fibrillation but also decrease unnecessary labor force and the cost.

\section{LIMITATIONS}

The main limitation of this study is that it is a cross-sectional study and Holter ECG following was done just in the first day of hospitalization. Long-term rhythm follow-up was not done when atrial fibrillation attacks were determined in Holter ECG. Additionally, the small number of patients and being one-centered is another limitation of our study. More accurate results can be obtained with long-term follow-up and higher number of patients.

\section{ACKNOWLEDGMENTS:}

We would like to thank Dr. Yılmaz İnanç and Dr. Cemile Buket Tugan Yildı for their contribution to our study and Dr. Murat Kerkütlüoğlu for applying echocardiographic and holter ECG examining.

\section{REFERENCES}

1. Adams HP Jr, Bendixen BH, Kappelle LJ, et al. 3rd. Classification of subtype of acute ischemic stroke. Definitions for use in a multicenter clinical trial. TOAST. Trial of Org 10172 in Acute Stroke Treatment. Stroke. 1993; 24(1): 35-41.

2. Wolf PA, Abbott RD, Kannel WB. Atrial fibrillation as an independent risk factor for stroke: the Framingham Study. Stroke. 1991; 22(8): 983-988.

3. Yetim E, Topcuoglu MA, Canpolat U,et al. Nonsustained Atrial Fibrillation in Ischemic Stroke Patients and Stroke-Free Controls From the Perspective of Stroke Pathophysiology. J Am Heart Assoc. 2016; 5(10): pii: e004021

4. Singer DE, Chang Y, Borowsky LH, et al. A new risk scheme to predict ischemic stroke and other thromboembolism in atrial fibrillation: the ATRIA study stroke risk score. J Am Heart Assoc. 2013; 2(3): e000250.

5. Van Den Ham HA, Klungel OH, Singer DE, et al. Comparative performance of ATRIA, CHADS2, and CHA2DS2-VASc risk scores predicting stroke in patients with atrial fibrillation in a national primary care database and the impact on treatment decisions. J Am Coll Cardiol 2015; 66: 1851-1859

6. Ziegler PD, Glotzer TV, Daoud EG, et al. Incidence of newly detected atrial arrhythmias via implantable devices in patients with a history of thromboembolic events. Stroke 2010; 41(2): 256-260.

7. Favilla CG, Ingala E, Jara J,et al . Predictors of finding occult atrial fibrillation after cryptogenic stroke. Stroke 2015; 46(5): 1210-1215.

8. Scheitz JF, Erdur H, Haeusler KG, et al. Insular cortex lesions, cardiac troponin, and detection of previously unknown atrial fibrillation in acute ischemic stroke: insights from the troponin elevation in acute ischemic stroke study. Stroke 2015; 46(5): 1196-1201.

9. Liu R, Yang X, Li S, et al. Modified CHADS(2) and CHA(2)DS(2)-VASc scores to predict atrial fibrillation in acute ischemic stroke patients. J Clin Neurosci. 2018 ; 51: 35-38.

10. Lang RM, Bierig M, Devereux RB,et al. Recommendations for chamber quantification: A report from the American Society of Echocardiography's Guidelines and Standards Committee and the Chamber Quantification Writing Group, developed in conjunction with the European Association of Echocardiography, a branch of the European Society of Cardiology. J. Am. Soc. Echocardiogr. 2005; 18: 1440-1463

11. Miyasaka Y, Barnes ME, Gersh BJ, et al. Secular trends in incidence of atrial fibrillation in Olmsted County, Minnesota, 1980 to 2000, and implications on the projections for future prevalence. Circulation 2006; 114(2):1191925.

12. Gbadebo TD, Okafor H, Darbar D. Differential impact of race and risk factors on incidence of atrial fibrillation. Am Heart J 2011; 162(1): 31-37.

13. Aksnes TA, Schmieder RE, Kjeldsen SE, et al.Impact of newonset diabetes mellitus on development of atrial fibrillation and heart failure in high-risk hypertension (from the VALUE Trial). Am J Cardiol 2008; 101(5): 634-638.

14. Zuo ML, Liu S, Chan KH, et al. The CHADS2 and CHA 2DS 2-VASc scores predict new occurrence of atrial 
fibrillation and ischemic stroke. J Interv Card Electrophysiol 2013; 37(1): 47-54.

15. Engdahl J, Andersson L, Mirskaya M, et al. Stepwise screening of atrial fibrillation in a 75-year-old population: implications for stroke prevention. Circulation 2013; 127(8): 930-937.

16. Kirchhof P, Benussi S, Kotecha D,et al. 2016 ESC Guidelines for the management of atrial fibrillation developed in collaboration with EACTS. Europace. 2016; 18(11): 1609-1678. 